\title{
Opinion
}

\section{Business and Investment Opportunities in Healthcare in Africa}

\author{
Babatunde Omilola, PhD; N'doh A. Sanogo, PhD* \\ Public Health, Security and Nutrition Division, The African Development Bank Group, Avenue Joseph Anoma, 0 I BP I387 Abidjan 0 I, Côte d'Ivoire
}

\section{*Corresponding author}

N'doh A. Sanogo, PhD

Consultant for the Public Health, Security and Nutrition Division, The African Development Bank Group, Avenue Joseph Anoma, 0 I BP I387 Abidjan 0I, Côte d'Ivoire; E-mail: n.sanogo@afdb.org

Article information

Received: February 12 ${ }^{\text {th }}, 2020$; Revised: March 2 ${ }^{\text {nd }}, 2020 ;$ Accepted: March $2^{\text {nd }}, 2020$; Published: March $4^{\text {th }}, 2020$

\section{Cite this article}

Omilola B,Sanogo NA. Business and investment opportunities in healthcare in Africa. Public Health Open J. 2020; 5(I): II-13. doi: I0.17| 40/PHOJ-5-139

\section{PROBLEM STATEMENT}

\begin{abstract}
$A s$ the cost of medical care continues to increase in many $\mathrm{A}_{\text {developed countries (e.g., United States), as well as in some }}$ developing nations, with no or little improvement in populationlevel health indicators (e.g., infant mortality), the limits to curative, clinical medicine becomes apparent. As a result, public health leaders and health system administrators turn to consider the roles that disease prevention and health promotion might play for improving population-level health status. ${ }^{1}$ The difference between clinical medicine and public health is not surprising. ${ }^{2}$ Some clinical medicine, public health, and health systems administration professionals recognize the role of data in identifying conditions that could be used in the diagnosis and treatment of individuals and the role of data in the development of public health policies or allocation of resources to prevent disease and promote health in populations. In this short communication, key terms of public health, population health, and population health management are defined and a role for data analytics is described to help health system administrators in thinking about population health management activities.
\end{abstract}

\section{BACKGROUND}

In the attempt to meet the Millennium Development Goals (MDGs) by 2015, Africa witnessed improvements in the overall health of its population over the past 20 -years. ${ }^{1}$ Life expectancy at birth rose from 50-years in 1990 to 60 -years by 2015 . Adults' mortality rate decreased from 361 to 300 deaths per 100000 people. Under-five mortality rate and maternal mortality ratio declined by $54.2 \%$ and $40.7 \%$ respectively over the same period. ${ }^{2,3}$ Regarding infectious diseases, human immunodeficiency virus (HIV) prevalence declined by $57 \%$, malaria incidence declined by $42 \%$ and mortality rates from tuberculosis declined by $31 \%$ during the MDGs era.
While Africa has made significant progress in health outcomes, ensuring universal access to quality healthcare remains a key challenge. Africa's health challenges include poor infrastructure, counterfeit drugs, shortage of health workers and poor access to quality health services. ${ }^{4} \mathrm{~A}$ large population, widespread poverty, and conflicts have all contributed to poor health outcomes experienced across the continent. ${ }^{4}$ With $24 \%$ of the global disease burden and $11 \%$ of the world's population, sub-Saharan Africa commands less than $1 \%$ of the world's health expenditure. ${ }^{5}$ Despite decades of foreign aid, approximately $36 \%$ of total health expenditure is financed by out-of-pocket payments. ${ }^{6,7}$ This means that health spending remains largely inadequate to meet the growing healthcare needs of the continent. Africa has a financing gap of at least US\$ 66 billion per year in the health sector.?

Despite all these constraints, business and investment opportunities in health in Africa are on the rise. ${ }^{6}$ By 2005, foreign investment in sub-Saharan Africa increased to $\$ 18$ billion from $\$ 6$ billion in $2000 .{ }^{6}$ Increasing political stability and steady economic growth continue to contribute to the improving investment climate. ${ }^{7}$ Studies estimate that $\$ 25-30$ billion in new investment is needed in healthcare assets to meet the growing healthcare demands of sub-Saharan Africa. ${ }^{6}$ The demand for private healthcare presents a growing opportunity, and could add an additional $\$ 20$ billion per year in investment.

It is clear that governments cannot meet all health costs in view of the huge financing gap and the changing disease profile in Africa. ${ }^{7}$ The private sector has an important role to play in helping countries in Africa achieve significant improvements in health outcomes. In light of the critical role the private sector plays in bridging the healthcare gap in Africa, it would benefit from enhanced regulations as well as financial and technical support to 
enforce quality standards where they may be lacking. ${ }^{6}$ In fact, most parts of Africa lack the infrastructure and facilities necessary to provide and deliver essential level of health services and products. Africa also faces a severe shortage of trained medical professional, with just 3\% of the world's health workers. ${ }^{8}$ The private health sector in Africa could help resolve these issues but it is large and fragmented, with inconsistent quality due to lack of regulatory frameworks. ${ }^{6}$ Reformation of local policies and regulations that impede the development of private sector is necessary, particularly in streamlining bureaucratic processes that limit market entry. ${ }^{6}$

\section{Advocating for the Role of the Private-Business Sector in Africa to Promote Health Systems}

In September 2018, on the margins of the United Nations General Assembly, the Global Business Coalition on Health (GBCHealth), the Aliko Dangote Foundation and the United Nations Economic Commission for Africa (ECA) jointly organized a high-level dialogue titled "Africa's Health and Finance: Pathways to Economic Growth and Prosperity". This dialogue allowed African heads of state and government leaders, chief executive officers (CEOs) and business leaders, philanthropists, as well as high-level representatives of the United Nations, and other multilateral organizations to discuss issues related to the status of health in Africa and economic growth. This dialogue pointed to the need to unlock synergies and help the private sector enhance its contribution to national and regional health goals with the resulting impact on Agenda 2030 for Sustainable Development and Africa Agenda 2063. The Africa Business Health Forum follows-up on the above recommendation. It took place in February 2019 in Addis Ababa on the side lines of the AU Summit, and brought together Africa's business leaders and a number of heads of state, ministers and health experts. The Forum culminated with the launch of the African Business Coalition for Health (ABCHealth), a platform to unlock synergies and shape markets for better health outcome in Africa.

\section{Caution-Reliability of Private-Sector in the Provision of Healthcare in Africa}

Many actors in the public health community are against the involvement of the private sector (particularly for profit entities) in healthcare. They always point to examples of poor quality, inefficiency, and a range of unethical business practices by the private sector. ${ }^{6}$ Indeed, there are too many examples in which the pursuit of excessive profits leads to unethical business practices such as under- or over-servicing, collusion, false billing, price gouging, unlicensed practice, substandard drugs (often resulting from small, sub-scale manufacturers without the skills, processes, and technologies required to produce higher standards) and counterfeit drugs (often linked to organized crime). ${ }^{6}$ For instance, a World Health Organization (WHO) survey of the quality of anti-malaria drugs in seven Sub-Saharan African nations found that the majority of drugs in private facilities (pharmacies, drug shops, street vendors) failed quality testing. ${ }^{6,8}$

\section{Important Role of the Private Sector and Public-Private Collaboration in Boosting the Health Systems of Africa}

Despite all the concerns about the involvement of the private sector in the health sector in Africa, a regulated private sector could help serve the poor and have a positive impact on the quality of care. The health and well-being sector has major market opportunities in Africa estimated to be about US $\$ 259$ billion by 2030, with the potential to create over 16 million jobs in Africa. ${ }^{7}$ It is estimated further that $14 \%$ of all business opportunities in health and wellbeing sector globally will arise in Africa, second only to North America with $21 \% .^{7}$ Many opportunities exist from healthcare service delivery (i.e. private hospitals and clinics), through support services (i.e. diagnostic and laboratory services); and supply chain and logistics to health financing (e.g. private insurance schemes). These actions could help sustain the achievement of MDGs for Africa over the long-term.

To achieve maximum impact in Africa's health sector, it is important to enhance collaboration between public and private sectors by recognizing diversity of the private sector and the mutual understanding of each other's identity and objectives in efforts to achieve universal health coverage (UHC) and improved health systems in Africa. ' Private sector providers should align closely with health needs and goals of countries where they are operating. Since the private sector is diverse (from Non-Governmental Organizations (NGOs) to religiously affiliated hospitals and from formal to informal establishments), it is therefore important for governments to map expectations relevant to each component of the private health sector, and to device clear strategies and plans to make these expectations a reality.

\section{SUMMARY}

The public and private sectors have different strengths and weaknesses, and a judicious blending of the two can produce optimal results. For many, Africa's business environment and the current role and potential of the private sector remains poorly understood. Their interest and potential impact in financing healthcare through production of health goods and pharmaceuticals as well as training of health personnel remains untapped. To achieve universal health coverage for African countries, it is important to highlight the necessary contribution of the private sector.

\section{DISCLAIMER}

This represents our personal opinion and not that of the Bank.

\section{CONFLICTS OF INTEREST}

The authors declare that they have no conflicts of interest.

\section{REFERENCES}

1. United Nations Economic Commission for Africa (UNECA), GBCHealth, the Aliko Dangote Foundation (ADF). Healthcare and Economic growth in Africa Web site. https://lnct.global/ resources/healthcare-and-economic-growth-in-africa/. Accessed February 11, 2020.

2. World Health Organization (WHO). Leave no one behing, Strengthening health systems for UHC and the SDGs in Africa 
Web site. https://www.afro.who.int/publications/leave-noone-behind-strengthening-health-systems-uhc-and-sdgs-africa. Accessed February 11, 2020.

3. World Bank, Japan International Cooperation Agency (JICA), The Global Fund, African Development Bank, World Health Organization (WHO). UHC in Africa: A framework for action Web site. https://www.who.int/health_financing/documents/ uhc-africa-action-framework/en/. Accessed February 11, 2020.

4. Clausen LB. Taking on the challenges of healthcare in Africa Web site. https://www.gsb.stanford.edu/insights/taking-challengeshealth-care-africa. Accessed February 11, 2020.

5. Klynveld Peat Marwick Goerdeler (KPMG). The State of Healthcare in Africa Web site. www.kpmgafrica.com. Accessed February 11, 2020.

6. International Finance Corporation (IFC). The Business of Health in Africa: Partnering with the Private Sector to Improve
People's Lives Web site. http://documents.worldbank.org/ curated/en/878891468002994639/The-business-of-health-inAfrica-partnering-with-the-private-sector-to-improve-peopleslives. 2008. Accessed February 11, 2020.

7. United Nations Economic Commission for Africa (UNECA), Global Business Coalition on Health (GBCHealth), Aliko Dangote Foundation. Healthcare and Economic Growth in Africa Web site. https://www.uneca.org/sites/default/files/uploaded-documents/ ABHF2019/healthreport_executive_summary.pdf. Accessed February 11, 2020.

8. International Finance Corporation (IFC). The Business of Health in Africa, Partnering with the Private Sector to Improve People's Lives. https://www.unido.org/sites/default/files/2016-01/IFC_ HealthinAfrica_Final_0.pdf. 2016. Accessed February 11, 2020.

9. African Development Bank Group (AfDB). AfDB Approach paper for advancing Universal Health Coverage in Africa. 2017. 